Egyptian Poultry Science Journal

http://www.epsaegypt.com

ISSN: 1110-5623 (Print) - 2090-0570 (On line)

\title{
GENETIC IMPROVEMENT OF EGG PRODUCTION TRAITS IN DOKKI-4 STRAIN \\ 1- CORRELATED RESPONSES HERITABILITY, GENETIC AND \\ PHENOTYPIC CORRELATIONS FOR EGG PRODUCTION AND EGG QUALITY TRAITS.
}

\author{
H. H. Younis, F.A.Abdel-Ghany ${ }^{1}$, and Nasra B Awadein ${ }^{1}$ \\ Poul. Prod. Dept., Fac. of Agric., Kafrelsheikh Univ. \\ ${ }^{1}$ Anim. Prod. Res. Inst., Agric. Res. Center, Minist. Of Agric., Egypt.
}

\begin{abstract}
Dokki-4 is a local strain selected for improving egg number during the first 90 days of laying. Genetic changes were estimated as deviations from its unselected control line per generation. This study was conducted to determine the effect of selection for two generations for egg production and egg quality. The results of selection for egg number during the first 90 days of laying showed:

- Average egg number during the first 90 days of laying of the base, first, and second generation were 43.9, 52.7 and 61.9 eggs for the selected line and 43.6, 44.8 and 46.1 eggs for control line, respectively. The cumulative realized response and expected response after two generations were 15.5 and 5.3 eggs, respectively.

- Selected line pullets matured earlier than those of the control line by -6.9 and -8.7 days for the first and the second generation. Also, the realized cumulative response after tow generations was 7.5 days.

- Average duration period of the first 10 eggs of the base, first and second generations were 26.4, 24.4 and 22.2 days for selected line. The selected pullets decreased in the duration period of first 10 eggs than those of the control line by -2.05 and -2.19 days for the first and second generations.

- Egg number till 45 and till 65 weeks of age were increased in the selected line compared with the control line during two generations by 21.1 and 25.9 eggs respectively.

- Selected line had significantly better egg mass and feed conversion during the first 90 days of laying, till 45 and 65 weeks of age than the control line.
\end{abstract}

Key Words: Correlated responses, heritability, correlations, egg production. 
- Selected pullets had better egg quality characteristics (thicker shell, higher shell and yolk percentages, and Haugh Units) when compared to the pullets of the control line. Most traits studied affected significantly $(\mathrm{P}<0.01)$ by generation.

- Heritability estimates for egg number during the first 90 days of laying, till 45 and till 65 weeks of age for selected line based on sire component of variance over two generation were $0.21,0.19$ and 0.23 , respectively.

- Negative genetic and phenotypic correlations were found between egg number and body weight at sexual maturity, age at sexual maturity, duration period of the first 10 eggs, feed conversion while positive correlations were found between egg number and egg mass. As for the quality of the eggs shape index and shell thickness were found negative with egg number and yolk\%, albumen \%, shell \% and Huagh Units were positive with egg number.

Generally, selection for egg number during the first 90 days of laying of Dokki-4 strain of chickens was able to increase egg number. This improvement was associated with early sexual maturity, high egg mass and better feed conversion. However, more studies are needed, in this strain (Dokki-4) to improve economic characteristics constantly.

\section{INTRODUCTION}

"Dokki-4" a local strain established on 1966 at the Dokki-4 Poultry Station. It originated from a cross between Fayoumi males and Plymouth Rock females (ElItriby and El- Sayed, 1966). The great demand for poultry products puts great emphasis on poultry breeders to do their best to improve and increase the production of their stocks. The study of the genetic parameters of the different economic traits, such as, egg number, egg weight, egg mass, age at sexual maturity and body weight at sexual maturity should be suggested in breeding plan. Egg production depends on many characters such as age at sexual maturity, egg number, egg weight, body weight, egg quality. Tawfeek (1988), Kosba et al, (1997) and Younis and Abd El-Ghany (2004) found that selection for egg number of Silver Montazah chickens increased egg production in association with early sexual maturity, high egg mass and better feed conversion. Selection differentials and realized heritability for egg production traits were reported by Soltan (1991) in Sinai fowl and ElWaradany and Abdou (1993) in Norfa strain, Younis and Abd El-Ghany (2004) in
Silver Montazah and Saleh et al., (2006) in Inshas strain. Relationships between the age at sexual maturity and some economic traits were reviewed by Shebl (1991), Ghanem (1995), Kosba et al. (1997) Abd El-Halim (1999), El-Tahawy (2000) and Younis and Abd El-Ghany (2004).

Response to selection is a function of intensity of selection, phenotypic variance and heritability and in theory should decline after continuous selection over generations because additive genetic variance is exhausted. In the great majority of single trait selection experiments, positive genetic progress for the trait selected, egg number or rate egg production, was presented, while in a few cases, genetic progress was absent or negative (Fairfull and Gowe, 1990). Abdou and Kolstad (1979) reported that phenotypic and genetic correlations between egg number and mature body weight at 42 weeks of age were 0.04 and 0.02 respectively in White Leghorn hens. Enab (1982) reported that the genetic correlations between egg number and egg weight were 0.21 and 0.42 in high egg number and high egg size line of White Leghorn, respectively. 
Heritability $\left(\mathrm{h}^{2}\right)$ of egg production traits have been cited by many researches on different local strain of chickens Abdou and Enab (1994); Abdou, (2006), Abd ElGhany (2005), (2006), and Saleh et al. (2006) on local strains. Weight at sexual maturity had different $\left(h^{2}\right)$ estimates, Singh et al.(1986) for exotic strains and AbdelHalim (1999) and Saleh et al.(2006) using local strains. Genetic and phenotypic correlations among egg production traits have been studied El-Wardany and Abdou (1993), Younis and Abd El-Ghany (2004), Abd-Ella (2006) and Saleh et al. (2006).

Egg quality characters are considered as an important economic policy in egg production. Islam et al., (2001) found that the external and internal egg quality traits of the breeds affecting performance differed among generations. The overall quality of an egg can be discussed under two broad categories namely external" and "internal" quality Monira et al., (2003) and Rayan et al., (2013). The external quality of the egg is determined by features such as the size and shape of the egg as well as the structure and thickness of the shell (Bain, 2005). The internal quality is measured on the basis of the quality of the albumen height, the relative size of the various internal components, and the integrity of the shell membrane have looked in several studies for assessment of egg quality in chickens (Bain,2005, Rizk et al., 2008, Cavero et al., 2011 and Shalan et al., 2012).Moreover, external and internal egg quality traits were significant in the poultry breeding for their influence on the yield features of the future generations, breeding performances, and quality and growth of the chicks (Aldin et al., 2006). The purpose of the present study was to improve egg production through selection in a population of local developed chickens "Dokki-4" and to measure the direct as well as correlated response to selection for some egg production traits.

\section{Material and Methods}

This experiment was carried out during three successive generations at the Poultry Research Center, Poultry Production Department, Faculty of Agriculture, Kafrelsheikh University, in collaboration with the Anim. Prod. Res. Inst. Agric. Res. Center, Minist. Of Agric., Egypt. Two lines of Dokki-4 strain were used: in the selected line females were selected according to their own performance egg number during 90 days of laying, while males were selected according to the performance of their halfsib females. In the control line, chicks were randomly chosen and was maintained without conscious selection.

\section{Genetic stock and management:}

Two hundred hens and twenty cocks from Dokki-4 strain at 18 weeks of age were used for initation of the selected line. The birds were assigned randomly into individual cages. On the other hand,the control group which contained 80 hens and 10 cockerels (8 females: 1 male) was placed in group cages and provided with the same management. The pullets were fed a laying diet (16\% crude protein and 2600 $\mathrm{Kcal} / \mathrm{kg}$ of diet). Feed and water were provided ad-libitum throughout the experimental period. The pullets were subjected to natural lightning, which was received about $14 \mathrm{hr}$ light per day. Egg number, duration period of first 10 eggs (day), egg weight, feed consumption, age at sexual maturity, were recorded individually daily after sexual maturity and calculated every 28 days, eggs were collected using individual cages through three periods the first 90 days of laying, till 45 weeks of age and at 65 weeks of age of laying, in each generation. Artificial insemination was applied according to Lake and Stewart (1978) and Mostafa (1989). All collected eggs were pedigreed individually from each dam and the percentages of fertility and hatchability were recorded. 
Egg quality at 90 days of laying, 45 and 65 weeks of age, utilizing eggs produced from Dokki-4 strain at different ages 120 egg per period in generation were examined for external and internal egg quality traits. Measurements were taken: egg weights in grams and egg shape index (width to length $\mathrm{x} 100$ ) according to Potts and Washburn (1983). After that, eggs were broken out on a flat surface and the heights of the albumen and yolk in millimeter were measured using Ames Triple Micrometer. Yolk was separated from the albumen and weighed. The weight of albumen was calculated as the difference between the egg weight and the weight of the shell and yolk. Shell plus membranes were weighed. Yolk index (height of yolk/ yolk diameter) was calculated according to wisely and Stadelman (1959). Yolk, albumen and shell were expressed as percentages of total egg weight. Shell thickness without membrane was also, measured at different three places of shell at broad end, equator and pointed end using a micrometer $(\mathrm{mm})$ and yolk/albumin ratio was estimated, Haugh units were calculated according to the formula of Haugh (1937) as follow Haugh units $(\mathrm{HU})=100 * \log (\mathrm{H}$ +7.57- $1.7 \mathrm{~W}^{0.37}$ ) where $\mathrm{H}=$ Albumin height (mm), W= Egg weight ( $\mathrm{g})$.

\section{Statistical analysis:}

- Selection differential was calculated as the difference between average of the selected parent for certain trait and the average of their mean of population (Falconer, 1989).

- Realized heritability estimates of the selected trait (egg number during the 1 st 90 days of laying) were obtained for each generation as the ratio of realized response to selection differential (Falconer, 1989).

- Density of selection (v) calculated by the following equation (Falconer, 1989) $\mathrm{V}=$ Number of selected Parents/Number of all population
- The realized genetic gain per generation was estimated as a deviation of the selected line mean from the control line mean according to the following equation $\mathrm{R}_{\mathrm{t}}=\left(\mathrm{St}-\mathrm{S}_{\mathrm{t}-1}\right)-\left(\mathrm{C}_{\mathrm{t}}-\mathrm{C}_{\mathrm{t}-1}\right)$

- Where: $R_{t}$ realized gain due to selection in the $t^{\text {th }}$ generation and $S$ and $\mathrm{C}$ averages performance of the selected and the control populations (Guill and Washburn, 1974).

- Data of egg production and egg quality traits were analyzed using SAS program (1988) and statistical model as follows:

\section{Fixed model:}

Yijk $=\mu+\mathrm{Gi}+\mathrm{Lj}+(\mathrm{GL})_{\mathrm{ij}}+\mathrm{e}_{\mathrm{ijk}}$

Where: $Y_{\mathrm{ijk}}=$ an observations, $\mu=$ overall mean, $\mathrm{Gi}=$ the fixed effect of $i^{\text {th }}$ generation, $\mathrm{L}_{\mathrm{j}}=$ the fixed effect of $\mathrm{j}^{\mathrm{th}}$ line,

$(\mathrm{GL})_{\mathrm{ij}}=$ effect of the interaction between generation and line, and $\mathrm{e}_{\mathrm{ijk}}=$ random error.

\section{Random Model:}

Yijk $=\mu+\mathrm{Si}+\mathrm{e}_{\mathrm{ijk}}$

Where: $Y_{\mathrm{ijk}}=$ an observations,

$\mu=$ overall mean, $\mathrm{Si}=$ the effect of $i^{\text {th }}$ sire and $\mathrm{e}_{\mathrm{ijk}}=$ random error

\section{RESULTS AND DISCUSSION}

Least square means and standard errors of egg number during the first 90 days of laying for the selected and control lines in the base, first and second generations are presented in Table (1). The means for egg number for the base, first and second generations were 43.9, 52.7 and 61.9 eggs for selected line and 43.6, 44.8 and 46.1 eggs for control line, respectively. It could be seen that the hens of the selected line in the first and second generations produced significantly $(p \leq 0.001)$ more eggs than those of the control line by 7.9 and 15.8 eggs, respectively. Moreover highly significant differences between generation and line. Similar results were reported by Soltan (1991) in Sinai fowl, El Wardany et al., 
(1992) in Norfa strain, Younis and Abd ElGhany (2004) in Silver Montazah strain, Abd El-Ghany (2005) and Saleh et al., (2006) in Inshas strain of chickens.

Selection differential values were 15.3 and 10.7 eggs (males) and 13.9 and 9.8 eggs (females) in the base and first generations. Moreover, selection density was 0.09 and 0.10 (males) and 0.41 and 0.43 (females) in the base and first generations, respectively. The realized and expected selection response were 15.5 and 5.7 eggs over two generations of selection for improving egg number during the first 90 days of laying. These results were nearly to those reported by Soltan (1991), Younis and Abd El-Ghany (2004), AbdelGhany (2005) and Saleh et al., (2006). In general, the results of the present study cleared that the realized response to improve egg number was higher than the expected genetic gain. This result may be due to inaccurate estimation of heritability of egg number because of big role of nonadditive effects or because of relatively small population.

\section{Correlated response:}

Age at sexual maturity: Least square means and standard errors of egg production traits for the selected and control lines during the three generations are presented in Table (2). The means of age at sexual maturity for the base, first and second generations were 162, 153.7 and 150.1 day for the selected line and 163.3, 160.6 and 158.8 day for the control line, respectively. It could be seen that the selected line pullets significantly $(p \leq 0.001)$ matured earlier than those of the control line by 6.9 and 8.7 in the first and second generations, respectively. The averages of age at sexual maturity for the two lines were lower than that reported by Younis and Abd El-Ghany (2004) for Silver Montazah strain 174.8, 168.1 days, Amin (2008) 184.2 days and Nawar (2009) 178.5 days for Mandarah strain. The realized response to selection for age at sexual maturity from generation was -5.7 days $\left(1^{\text {st }}\right.$ generation), -1.8 days ( $2^{\text {nd }}$ generation) and 7.5 days (cumulative response). Moreover, the results indicted that decreasing age at sexual maturity of selected line reflected the effect of selection for improving egg number in Dokki-4 strain of chicken. Values obtained herein were in harmony with those reported by Younis and Abd ElGhany (2004), Abdel-Ghany (2005), Saleh et al., (2006) and Abd-Ella (2006).

Duration period of the first 10 eggs: The period required by the hens to produce the first ten eggs in Dokki-4 strain as affected by generation and lines are shown in Table (2). Highly significant $(p \leq 0.01)$ difference were observed among generations and lines. The pullets in the second generation had the lowest days to produce the first ten eggs compared to in the base and first generation. The selected and control pullets produce the first ten eggs during 24.4 and 26.5 days $\left(1^{\text {st }}\right.$ generation) and 22.2 and 25.4 days $\left(2^{\text {nd }}\right.$ generation), respectively.. The realized response were -1.35 days and -1.13 days in the $1^{\text {st }}$ and $2^{\text {nd }}$ generations as well as -2.48 days (cumulative response). Similar results were reported by Saleh et al (200 6) and Enayat (2006) in Inshas strain of chicken where the duration of the first ten eggs were 27.5 and 31.9 days for selected and control (first generation) and 25.54 and 32.37 days (second generation), respectively. In contrary, average duration period of the first ten eggs ranged from 12.9 days to 15.2 days in Alexandria chickens (Abd El-Halim (1999), ElTahawy (2000) Kosba et al., (2002) and Ghanem (2003).

Body weight: Body weight at sexual maturity and body weight at the first 90 days of laying and at 65 weeks of age were measured, no significant differences were observed among generations while the control line had significantly $(\mathrm{p} \leq 0.05)$ heavier body weigh than those the selected line. These results may be due to negative genetic and phenotypic correlations 
between egg number and body weight at three age in the present study. Similar results were reported by Soltan (1991), ElWardany et al., (1992) they reported that selection for egg number leads to decrease body weight of males and females at late ages in Sinai fowl and Norfa strain of chicken. Selection for improving egg number during the first 90 days of laying caused slightly decreasing body weight at sexual maturity, at 90 days of laying and at 65 weeks of age, where the cumulative realized response was $-6.00,-54.3$ and $36.8 \mathrm{gm}$, respectively. Values obtained herein were in harmony with those reported by Younis and Abd El-Ghany (2004), Abdel-Ghany (2005), Saleh et al., (2006) and Abd-Ella (2006).

Egg number: Selection for improving egg number during the first 90 days of laying affected egg number at 45 weeks of age. It was noticed that means of egg number produced by selected line was higher and highly significant values than control line, where egg numbers were 89.6, 108.2 and 119.4 eggs for selected line, and 88.6, 92.9 and 97.3 eggs for control line in the base, first and second generations, respectively. The realized response to selection for this trait had a high and a positive value 14.3 eggs and 6.8 eggs in the $1^{\text {st }}$ and $2^{\text {nd }}$ generations (Table 4 ) and 21.10 eggs (cumulative response). Also, the same trend was observed for egg number till 65 weeks of age, where egg numbers were 176.8, 195.6 and 201.1 eggs for selected line and 176.1, 178.4 and 174.5 eggs for control line in the base, first and second generations, respectively. The realized response to selection for this trait had a high and a positive value 16.5 eggs and 9.4 eggs in the $1^{\text {st }}$ and $2^{\text {nd }}$ generations (Table 4) and 25.9 eggs (cumulative response). As general, selection for improving egg number during the first 90 days of laying had favorable effect on egg number till 45 and 65 weeks of age after two generations. Selection for increasing egg number had favorable effect on egg number till 60 or 65 weeks of age (ElWrdany et al., 1992 in Norfa strain, Younis and Abd El-Ghany, 2004 in Silver Montazah strain and Saleh et al., (2006) in Inshas strain of chickens.

Egg weight and egg mass: Highly significant differences between selected and control lines over the two generations for egg weight and egg mass during the first 90 days, till 45 and till 65 weeks of age were detected. The cumulative realized response to selection for egg weight during the first 90 days of laying, till 45 and 65 weeks of age was $-0.42,-0.20$ and -0.13 gm, respectively. Also, the cumulative response for egg mass during the three periods was $723.6,953.4$ and $1226.7 \mathrm{gm}$, respectively. These results indicated that selection for improving egg number decreased egg weight after two generations may be due to negative genetic and phenotypic correlations between egg number and egg weight. However, selection for increasing egg number was clear affect egg mass during the periods of laying. This result may be due to high and positive genetic and phenotypic correlations were found in the present study. Similar results were reported by Soltan, (1991), Sharma et al., (1998), Younis and Abd El-Ghany (2004), Abd ElGhany (2005), Saleh et al (2006) and Enayat (2006).

Feed conversion: feed conversion during the 90 days after sexual maturity, 45 weeks and 65 weeks of age presented in Table (2). Significant differences were found between selected and control lines, as well as among generations. Selected line had better feed conversion than control line in the $1^{\text {st }}$ and 2 nd generations during the three periods. The cumulative realized response to selection for feed conversion during the first 90 days of laying, till 45 and 65 weeks of age was $-1.17,0.76$ and 0.75 , respectively. These results were closely in agreement to those reported by Salah et al., (1994), El-Sayed et al., (2001) and Younis and Abd El-Ghany (2004), who 
reported that the feed conversion for egg production in Silver Montazah ranged from 4.0 to $6.5 \mathrm{~kg}$ feed/ $\mathrm{kg}$ egg.

Egg quality traits: Egg shape index, egg yolk \%, egg albumin\%, egg shell\%, egg shell thickness and Haugh units are presented in Table (3). Significant differences were found between the three generations and the two lines studied. Egg quality as affected by layer age, the present results revealed that there was a significant decrease in egg shape index with advanced of layers age. Similar trend with reported by Brand et al., (2004) and Rayan et al., (2013). They pointed that shape index of the eggs decreased with age because shape index is directly proportional to egg with and it is inversely related to egg length, which implies that with increasing age, the rate at which eggs become longer is faster than rate of being wider. Significant differences were found between the two lines studied, where eggs produced by the control pullets were heavier compared to those of the selected line (50.37 vs. 49.33 gm), Also, eggs of the control line had higher averages of egg albumen\% (56.42 vs. $54.91 \%$ ), and Hugh Unit (83.97 vs. 81.77) compared with those of selected line. Egg shell \% was significant affect by layer age, Therefore, the reason for heavier eggshells of older layers might be their production of heavier eggs than those of young, and shell percentage can be use to estimate the eggshell quality (Mertens et al., 2006). The present results showed that the shell percentage decreases gradually with advancing of hen's ages. The mean values were $11.22,10.78$ and $10.26 \%$, respectively for selected line and were 10.63, 10.52 and $10.06 \%$ respectively for control line. Similar trend was noticed by Suk and Park (2001), Robert, (2004), Singh et al., (2009), Aly et al., (2010) and Rayan et al., (2013). Shell thickness with membranes (mm) was significant affect by layer age Table (3). It could be observed shell thickness with membranes decreases with advancing of hens ages. In agreement with these finding,
Suk and Park (2001) pointed that eggshell thickness decreased with advancing of hens age.

Data presented in Table (3) showed internal egg quality traits (Albumen and Yolk\%) as affected by layer ages, whereas the albumen weight increases with advancing of layers ages. Similar result was obtained by Suk and Park (2001) observed that the albumen weight increased with advancing age of layers Also, the albumen percentages were significantly affected by layers ages, this results in accordance with Chiericato (2005). Haugh unit was significant affected by layer age Table (3). It could be observed Haugh unit decreases with advancing of hens ages. In agreement with these findings, Yasmeen et al., (2008) also found that Haugh unit values decreased with advancing the layers age.The yolk weight increases with advancing of layers ages. Similar trend was observed by Yasmeen et al., (2008), Singh et al., (2009) and Rayan et al., (2013).

The realized response to selection for egg shape index were 2.15 and -0.64 in the $1^{\text {st }}$ and 2nd generations and 1.52 (cumulative response), yolk \% were 0.92 and 0.63 in the $1^{\text {st }}$ and 2nd generations and 1.55 (cumulative response), albumen \% were -0.71 and -0.94 in the $1^{\text {st }}$ and 2 nd generations and -1.60 (cumulative response), egg shell \% 0.17 and 0.31 in the $1^{\text {st }}$ and 2nd generations and 0.48 (cumulative response), egg shell thickness were 0.02 and 0.01 in the $1^{\text {st }}$ and 2 nd generations and $-1.29 \mathrm{gm}$ (cumulative response), and for haugh unit were 2.59 and -0.39 in the $1^{\text {st }}$ and 2 nd generations and -1.29 gm (cumulative response). Significant interactions between generation and line were found concerning egg shell thickens and egg shell \% $(\mathrm{P}<0.05)$, in this study are in the range to those reported by Balat et al. (1995), Amin (2008) and Nawar (2009) for Mandarah strain. Control pullet eggs exhibited significantly higher values of Haugh unit than those of the selected. Many factors have been reported to affect 
Haugh units such as strain, storage time, and temperature, age of birds, nutrition and disease (Toussant and Latshaw, 1999). Akhtar et al. (2007).

\section{Heritability:}

The estimated heritability $\left(\mathrm{h}^{2}\right)$ were obtained according to sire variance component of egg production traits for selected lines are presented in Table (5), The heritabilty estimates of age at sexual maturity over two generations were moderate $(0.38 \pm 0.03)$. Result in the present study is lower than those reported by Balat et al, (2008) reported that the heritability estimates of age at sexual maturity over two generations in Mandarh (0.68)) and it was heaver than those reported by Hamdy et al., (1985) who reported that the average heritability of age at sexual maturity was 0.10 based on sire component of variance. Shalan et al., (2010) reported the heritability of age at sexual maturity was $0.22 \pm 0.13$ for Baheij strain. These result agrees with those reported by El-Full (2001), Ghanem (2003) and Kosba et al., (2006), and reflected the possibility of improving egg production through selection for early sexually maturity birds. The $\mathrm{h}^{2}$ estimates of body weight at sexual maturity over two generations was moderate $(0.24 \pm 0.21)$ for selected line. These results are lower than those reported by Ghanem (2003); Abd-Ella (2006); Balat et al, (2008) and Shalan et al., (2010) who reported heritability body weight at sexual maturity was $0.34 \pm 0.034$ for Baheij strain. Approximately equal values were found by Kosba et al., (2006). The $\mathrm{h}^{2}$ estimates of duration period of the first 10 eggs over two generations were low $(0.19 \pm 0.16)$. These results are lower than those reported by Saleh et al., (2006), Ghanem (2003) found that moderate and high heritability estimates for this trait indicate high possibility for duration period of the first ten eggs to be used as a selection criterion for egg production, taking in consideration the results of genetic correlation estimates.
The heritability estimates of egg number at the first 90 days of laying over two generations were moderate $(0.21 \pm 0.33)$. These results are lower than those reported by Saleh et al., (2006), Similar estimates were found with Kosba et al, (2002); Younis and Abd El-Ghany (2004); Abd ElGhany (2005); Balat et al, (2008) and Shalan et al., (2010) they reported the heritability of egg number was 0.40 for Baheij strain. The heritability estimates of egg weight at the three periods in the present study over two generations were moderate $0.42,0.29$ and 0.41 , respectively. The results agrees with those reported by Kosba et al.(1997) and Balat et al.(2008). But, these results are lower than those reported by El-Full (2001), Enab et al., (2001). Concerning egg mass, the $\mathrm{h}^{2}$ estimates of egg mass were moderate and ranged from 0.38 to 0.51 . These values were agreement with those reported by Abd-Ella (2006); Saleh et al., (2006) and Balat et al. (2008). While, Shalan et al., (2010) reported the $h^{2}$ for egg mass was $0.032 \pm 0.033$ for Baheij strain. Concerning, feed conversion at the three periods the heritability estimates were moderate for the selected line. This result indicated that selection affected the heritability estimates as found by Kosba et al., (2002) and Balat et al. (2008) who reported that heritability increased by selection.

Heritability estimates for egg quality studied traits for Dokki-4 strain presented in Table (5), $\mathrm{h}^{2}$ estimates of egg shape index, yolk percentage, shell percentage, shell thickness and Haugh unit were moderate $(0.25 \pm 0.123,0.39 \pm 0.328$, $0.29 \pm 0.232, \quad 0.32 \pm 0.421,0.21 \pm 0.314$ and $0.28 \pm 0.121$ ), respectively, these results are lower than those obtained by Shalan et al., (2012) and Ghanem and Yousria (2013), while, it was moderate estimates in albumen percentage (Albumen\%) $0.46 \pm 0.188$. These results are consisted with those mentioned by Zhang et al., (2005) and Shalan et al., (2012), and they 
were in good agreement with that estimated by Abdou and Kolestad (1979); ElWardany and Abdou (1993); Enab et al.(2000); Kosba et al.,(2002); Younis and Abd El-Ghany (2004); Balat et al, (2008). and Shalan et al., (2010).

\section{Genetic and Phenotypic correlations:}

Change in heritability and other parameters of population over many generations of selective breeding are necessary for understanding of the problems involved in the formulation of efficient breeding plans for partial improved flocks (Balat et al., 2008). The genetic $\left(r_{g}\right)$ and Phenotypic $\left(r_{p}\right)$ correlation coefficients for egg production are presented in Table (5). Results revealed negative genetic and phenotypic correlation coefficients over two generations were found between egg number and body weight at sexual maturity $(-0.561)$, the corresponding estimates for phenotypic correlation were small and negative (0.191). In contrary, positive genetic and phenotypic correlation was found by ElWardany and Abdou (1993) and Younis and Abd El-Ghany (2004). Negative genetic and phenotypic correlations were observed between egg number and age at sexual maturity (-0.32 and -0.37$)$ and duration period of the first ten eggs $(-0.68$ and -0.471$)$. These results mean that pullets of high egg number reached sexual maturity earlier. Simlar results were found by El- Wardany and Abdou (1993); Younis and Abd El-Ghany (2004) and Saleh et al.,(2006). Moreover, negative genetic and phenotypic correlation between egg number and egg weight at 45 weeks of age
( -0.53 and -0.43 ), several studies reported that the genetic and phenotypic correlations between egg number and egg weight were negative (Shebl et al., 1991; El-Wardany et al., 1992 and Salah et al., 2006). However, positive genetic and phenotypic correlations were found between egg number and egg mass at 45 weeks of age (0.71 and 0.86). Similar results were reported by Younis and Abd El-Ghany (2004), Abd El-Ghany (2005) and Salah et, al., (2006). Negative genetic and phenotypic correlations were observed between egg number and feed conversion. These results are in agreement with those reported by Shebl et al., (1991), Enab et al.,(2001), Abd El-Ghany (2005), Abdella (2006), Enayat, (2006), Saleh et al., (2006) and Balat et al.,(2008). Aly et al., (2010 b); and Shalan et al., (2012).

The genetic $\left(r_{g}\right)$ and Phenotypic $\left(r_{p}\right)$ correlation coefficients for egg quality are presented in Table (5). Results revealed that genetic and phenotypic correlation coefficients had fluctuated values between negative and positive for egg quality traits and egg number. These results are keeping with those mentioned by Zhang et al., (2005) and Aly et al., (2010).

Generally, selection for egg number during the first 90 days of laying of Dokki4 strain of chickens was able to increase egg production. This improvement was associated with early sexual maturity, high egg mass and better feed conversion. However, more studies are needed, in this strain (Dokki-4) to improve economic characteristics constantly. 
Table (1): L.S.M. \pm S.E. for egg number during the first 90 days of laying as well as selection differential (S) realized response (R) and expected response (ER) days for the selected and control lines during the two generations of selection.

\begin{tabular}{|l|l|l|l|l|l|l|l|l|}
\hline \multirow{2}{*}{ G* } & \multicolumn{2}{|c|}{ Selected Line } & \multicolumn{2}{c|}{ Control Line } & \multicolumn{2}{c|}{ S } & \multirow{2}{*}{ R } & \multirow{2}{*}{ ER } \\
\cline { 2 - 8 } & \multicolumn{1}{|c|}{ No. } & \multicolumn{1}{c|}{$\mathbf{X} \pm$ SE } & No. & \multicolumn{1}{|c|}{$\mathbf{X} \pm$ SE } & Males & Females & & \\
\hline G0 & 200 & $43.9 \pm 0.63$ & 80 & $43.6 \pm 0.51$ & 15.3 & 13.9 & & \\
G1 & 190 & $52.7 \pm 0.70$ & 100 & $44.8 \pm 0.29$ & 10.7 & 9.8 & 7.6 & 3.1 \\
G2 & 166 & $61.9 \pm 0.66$ & 100 & $46.1 \pm 0.32$ & $\ldots \ldots$ & $\ldots \ldots$ & 7.9 & 2.2 \\
CR & $\ldots \ldots$. & $\ldots \ldots$ & $\ldots \ldots$ & $\ldots \ldots$ & $\ldots \ldots$ & $\ldots \ldots$. & 15.5 & 5.3 \\
\hline
\end{tabular}

$* \mathrm{G}=$ Generation, $\mathrm{CR}=$ Cumulative response

Table 2: Means \pm S. E. for economic traits during the base, first and second generations.

\begin{tabular}{|c|c|c|c|c|c|c|c|}
\hline \multirow{2}{*}{ Traits } & \multirow{2}{*}{$\begin{array}{c}\text { Line } \\
\text { (L) }\end{array}$} & \multicolumn{3}{|c|}{ Generations (G) } & \multicolumn{3}{|c|}{ Significances } \\
\hline & & G0 & G1 & G2 & G & $\mathbf{L}$ & G*L \\
\hline $\begin{array}{l}\text { Age at sexual } \\
\text { maturity, day. }\end{array}$ & $\begin{array}{l}\mathrm{S} \\
\mathrm{C}\end{array}$ & $\begin{array}{l}162.1 \pm 0.65 \\
163.3 \pm 1.04\end{array}$ & $\begin{array}{l}153.7 \pm 0.99 \\
160.6 \pm 0.98\end{array}$ & $\begin{array}{l}150.1 \pm 0.91 \\
158.8 \pm 0.88\end{array}$ & ** & ** & $*$ \\
\hline $\begin{array}{l}\text { Duration period of } \\
\text { the first } 10 \text { eggs, day. }\end{array}$ & $\begin{array}{l}\mathrm{S} \\
\mathrm{C}\end{array}$ & $\begin{array}{l}26.4 \pm 0.35 \\
27.2 \pm 0.33\end{array}$ & $\begin{array}{l}24.4 \pm 0.19 \\
26.5 \pm 0.12\end{array}$ & $\begin{array}{l}22.19 \pm 0.08 \\
25.4 \pm 0.10\end{array}$ & ** & ** & $*$ \\
\hline $\begin{array}{l}\text { Body weight at } \\
\text { sexual maturity, g. }\end{array}$ & $\begin{array}{l}\mathrm{S} \\
\mathrm{C}\end{array}$ & $\begin{array}{l}1466 \pm 3.42 \\
1468 \pm 5.14\end{array}$ & $\begin{array}{l}1455 \pm 2.84 \\
1474 \pm 4.60\end{array}$ & $\begin{array}{l}1457 \pm 3.41 \\
1477 \pm 4.62\end{array}$ & NS & $*$ & NS \\
\hline $\begin{array}{l}\text { Body weight at } 90 \\
\text { day of laying, g. }\end{array}$ & $\begin{array}{l}\mathrm{S} \\
\mathrm{C}\end{array}$ & $\begin{array}{l}1574 \pm 4.94 \\
1579 \pm 7.85\end{array}$ & $\begin{array}{l}1533 \pm 3.24 \\
1582 \pm 6.16\end{array}$ & $\begin{array}{l}1552 \pm 5.00 \\
1612 \pm 8.38\end{array}$ & NS & $*$ & NS \\
\hline $\begin{array}{l}\text { Body weight at } 65 \\
\text { wks, g. }\end{array}$ & $\begin{array}{l}\mathrm{S} \\
\mathrm{C}\end{array}$ & $\begin{array}{l}1720 \pm 5.32 \\
1745 \pm 10.23\end{array}$ & $\begin{array}{l}1663 \pm 3.29 \\
1734 \pm 3.74 \\
\end{array}$ & $\begin{array}{l}1647 \pm 3.51 \\
1708 \pm 6.36\end{array}$ & NS & ** & $*$ \\
\hline $\begin{array}{l}\text { Egg number till } 45 \\
\text { wks, egg. }\end{array}$ & $\begin{array}{l}\mathrm{S} \\
\mathrm{C}\end{array}$ & $\begin{array}{l}89.6 \pm 0.98 \\
88.6 \pm 0.99\end{array}$ & $\begin{array}{l}108.2 \pm 0.39 \\
92.9 \pm 0.93\end{array}$ & $\begin{array}{l}119.4 \pm 0.60 \\
97.3 \pm 1.54\end{array}$ & ** & ** & * \\
\hline $\begin{array}{l}\text { Egg number till } 65 \\
\text { wks, egg. }\end{array}$ & $\begin{array}{l}\mathrm{S} \\
\mathrm{C}\end{array}$ & $\begin{array}{l}176.8 \pm 2.19 \\
176.1 \pm 1.76 \\
\end{array}$ & $\begin{array}{l}195.6 \pm 1.78 \\
178.4 \pm 1.68 \\
\end{array}$ & $\begin{array}{l}201.1 \pm 1.22 \\
174.5 \pm 0.86\end{array}$ & $* *$ & $* *$ & $*$ \\
\hline $\begin{array}{lll}\text { Egg weight at } 90 \\
\text { days, g. }\end{array}$ & $\begin{array}{l}\mathrm{S} \\
\mathrm{C}\end{array}$ & $\begin{array}{l}47.8 \pm 0.05 \\
47.9 \pm 0.11\end{array}$ & $\begin{array}{l}47.9 \pm 0.05 \\
48.4 \pm 0.11\end{array}$ & $\begin{array}{l}48.2 \pm 0.08 \\
48.6 \pm 0.09\end{array}$ & $*$ & $* *$ & $*$ \\
\hline $\begin{array}{l}\text { Egg weight (45 wks), } \\
\text { g. }\end{array}$ & $\begin{array}{l}\mathrm{S} \\
\mathrm{C}\end{array}$ & $\begin{array}{l}48.7 \pm 0.06 \\
50.1 \pm 0.04 \\
\end{array}$ & $\begin{array}{l}48.9 \pm 0.06 \\
50.4 \pm 0.11 \\
\end{array}$ & $\begin{array}{l}48.5 \pm 0.04 \\
50.6 \pm 0.08\end{array}$ & ** & $* *$ & $*$ \\
\hline $\begin{array}{l}\text { Egg weight (65 wks), } \\
\text { g. }\end{array}$ & $\begin{array}{l}\mathrm{S} \\
\mathrm{C}\end{array}$ & $\begin{array}{l}50.1 \pm 0.04 \\
51.1 \pm 0.04 \\
\end{array}$ & $\begin{array}{l}51.50 \pm 0.13 \\
50.6 \pm 0.03 \\
\end{array}$ & $\begin{array}{l}50.4 \pm 0.06 \\
50.9 \pm 0.05 \\
\end{array}$ & $* *$ & $* *$ & $*$ \\
\hline $\begin{array}{l}\text { Egg mass at } 90 \text { days, } \\
\text { g. }\end{array}$ & $\begin{array}{l}\mathrm{S} \\
\mathrm{C}\end{array}$ & $\begin{array}{l}2098 \pm 30.65 \\
2086 \pm 42.56 \\
\end{array}$ & $\begin{array}{l}2520 \pm 29.37 \\
2164 \pm 34.88 \\
\end{array}$ & $\begin{array}{l}2979 \pm 30.11 \\
2243 \pm 55.52 \\
\end{array}$ & $* *$ & ** & $* *$ \\
\hline $\begin{array}{llll}\text { Egg mass (till } 45 \\
\text { wks), g. }\end{array}$ & $\begin{array}{l}\mathrm{S} \\
\mathrm{C}\end{array}$ & $\begin{array}{l}4363 \pm 49.73 \\
4439 \pm 48.90\end{array}$ & $\begin{array}{l}5290 \pm 20.09 \\
4678 \pm 49.52\end{array}$ & $\begin{array}{l}5795 \pm 29.79 \\
4418 \pm 77.48\end{array}$ & $* *$ & $* *$ & $* *$ \\
\hline $\begin{array}{lll}\text { Egg mass (till } 65 \\
\text { wks), g. }\end{array}$ & $\begin{array}{l}\mathrm{S} \\
\mathrm{C}\end{array}$ & $\begin{array}{l}8861 \pm 99.06 \\
9005 \pm 89.69 \\
\end{array}$ & $\begin{array}{l}9842 \pm 89.13 \\
9187 \pm 89.42 \\
\end{array}$ & $\begin{array}{l}10143 \pm 58.2 \\
9061 \pm 44.30 \\
\end{array}$ & $* *$ & $* *$ & $* *$ \\
\hline $\begin{array}{l}\text { Feed conversion at } 90 \\
\text { days of laying. }\end{array}$ & $\begin{array}{l}\mathrm{S} \\
\mathrm{C}\end{array}$ & $\begin{array}{l}4.52 \pm 0.11 \\
4.56 \pm 0.15\end{array}$ & $\begin{array}{l}3.72 \pm 0.06 \\
4.41 \pm 0.10\end{array}$ & $\begin{array}{l}3.01 \pm 0.03 \\
4.22 \pm 0.11\end{array}$ & $* *$ & $* *$ & $*$ \\
\hline $\begin{array}{l}\text { Feed conversion at } 45 \\
\text { wks. }\end{array}$ & $\begin{array}{l}\mathrm{S} \\
\mathrm{C}\end{array}$ & $\begin{array}{l}3.94 \pm 0.07 \\
3.88 \pm 0.08\end{array}$ & $\begin{array}{l}3.05 \pm 0.01 \\
3.67 \pm 0.04\end{array}$ & $\begin{array}{l}2.76 \pm 0.01 \\
3.46 \pm 0.08\end{array}$ & $* *$ & $* *$ & * \\
\hline $\begin{array}{l}\text { Feed conversion at } 65 \\
\text { Wks. }\end{array}$ & $\begin{array}{l}\mathrm{S} \\
\mathrm{C}\end{array}$ & $\begin{array}{l}4.71 \pm 0.09 \\
4.62 \pm 0.08\end{array}$ & $\begin{array}{l}4.13 \pm 0.03 \\
4.54 \pm 0.06 \\
\end{array}$ & $\begin{array}{l}3.92 \pm 0.02 \\
4.63 \pm 0.03\end{array}$ & ** & ** & $*$ \\
\hline
\end{tabular}

Line: $\mathrm{S}=$ Selected line \& $\mathrm{C}=$ Control line

$\mathrm{NS}=$ Non significant, $*$ significant at $1 \%$ level of probability and ** significant at $5 \%$ level of probability 
Table 3: Means \pm S. E. for egg quality traits during the base, first and second generations.

\begin{tabular}{|c|c|c|c|c|c|c|c|}
\hline \multirow{2}{*}{ Traits } & \multirow{2}{*}{$\begin{array}{c}\text { Line } \\
\text { (L) }\end{array}$} & \multicolumn{3}{|c|}{ Generations (G) } & \multicolumn{3}{|c|}{ Significances } \\
\hline & & G0 & G1 & G2 & $\mathbf{G}$ & $\mathbf{L}$ & $\mathbf{G} * \mathbf{L}$ \\
\hline $\begin{array}{l}\text { Shape index at } 90 \\
\text { days of laying. }\end{array}$ & $\begin{array}{l}\mathrm{S} \\
\mathrm{C}\end{array}$ & $\begin{array}{l}80.6 \pm 0.28 \\
79.7 \pm 0.21\end{array}$ & $\begin{array}{l}83.9 \pm 0.10 \\
80.8 \pm 0.18\end{array}$ & $\begin{array}{l}82.9 \pm 0.17 \\
79.8 \pm 0.16\end{array}$ & $*$ & $* *$ & NS \\
\hline $\begin{array}{l}\text { Shape index at } 45 \\
\text { wks. }\end{array}$ & $\begin{array}{l}\mathrm{S} \\
\mathrm{C}\end{array}$ & $\begin{array}{l}79.6 \pm 0.17 \\
78.1 \pm 0.15\end{array}$ & $\begin{array}{l}81.5 \pm 0.28 \\
79.1 \pm 0.34\end{array}$ & $\begin{array}{l}81.8 \pm 0.27 \\
78.1 \pm 0.14\end{array}$ & $*$ & $* *$ & NS \\
\hline $\begin{array}{l}\text { Shape index at } 65 \\
\text { wks. }\end{array}$ & $\begin{array}{l}\mathrm{S} \\
\mathrm{C}\end{array}$ & $\begin{array}{l}78.2 \pm 0.12 \\
77.9 \pm 0.09\end{array}$ & $\begin{array}{l}80.7 \pm 0.17 \\
78.1 \pm 0.26\end{array}$ & $\begin{array}{l}80.6 \pm 0.37 \\
77.8 \pm 0.24\end{array}$ & Ns & $*$ & Ns \\
\hline $\begin{array}{l}\text { Yolk \% at } 90 \text { days } \\
\text { of laying. }\end{array}$ & $\begin{array}{l}\mathrm{S} \\
\mathrm{C}\end{array}$ & $\begin{array}{l}32.9 \pm 0.11 \\
32.8 \pm 0.27\end{array}$ & $\begin{array}{l}33.8 \pm 0.16 \\
32.9 \pm 0.31\end{array}$ & $\begin{array}{l}34.9 \pm 0.43 \\
32.2 \pm 0.22\end{array}$ & $* *$ & $*$ & $*$ \\
\hline Yolk \% at 45 wks. & $\begin{array}{l}\mathrm{S} \\
\mathrm{C}\end{array}$ & $\begin{array}{l}33.1 \pm 0.21 \\
33.0 \pm 0.43\end{array}$ & $\begin{array}{l}34.4 \pm 0.24 \\
33.8 \pm 0.19\end{array}$ & $\begin{array}{l}35.4 \pm 0.15 \\
33.9 \pm 0.32\end{array}$ & $*$ & $* *$ & $*$ \\
\hline Yolk \% at 65 wks. & $\begin{array}{l}\mathrm{S} \\
\mathrm{C}\end{array}$ & $\begin{array}{l}33.9 \pm 0.14 \\
33.9 \pm 0.19\end{array}$ & $\begin{array}{l}35.4 \pm 0.27 \\
34.7 \pm 0.16\end{array}$ & $\begin{array}{l}36.4 \pm 0.24 \\
34.9 \pm 0.11\end{array}$ & $* *$ & $* *$ & $*$ \\
\hline $\begin{array}{l}\text { Albumen \% at } 90 \\
\text { days of laying. }\end{array}$ & $\begin{array}{l}\mathrm{S} \\
\mathrm{C}\end{array}$ & $\begin{array}{l}57.0 \pm 0.08 \\
57.8 \pm 0.18\end{array}$ & $\begin{array}{l}55.6 \pm 0.11 \\
56.3 \pm 0.19\end{array}$ & $\begin{array}{l}55.3 \pm 0.21 \\
56.1 \pm 0.24\end{array}$ & $* *$ & $* *$ & NS \\
\hline $\begin{array}{l}\text { Albumen \% at } 45 \\
\text { wks. }\end{array}$ & $\begin{array}{l}\mathrm{S} \\
\mathrm{C}\end{array}$ & $\begin{array}{l}56.4 \pm 0.14 \\
56.2 \pm 0.34 \\
\end{array}$ & $\begin{array}{l}54.8 \pm 0.42 \\
56.1 \pm 0.13 \\
\end{array}$ & $\begin{array}{l}53.9 \pm 0.37 \\
55.5 \pm 0.02 \\
\end{array}$ & $* *$ & $* *$ & NS \\
\hline $\begin{array}{l}\text { Albumen } \% \text { at } 65 \\
\text { wks. }\end{array}$ & $\begin{array}{l}\mathrm{S} \\
\mathrm{C}\end{array}$ & $\begin{array}{l}56.1 \pm 0.25 \\
56.1 \pm 0.27\end{array}$ & $\begin{array}{l}54.7 \pm 0.37 \\
55.3 \pm 0.12\end{array}$ & $\begin{array}{l}52.4 \pm 0.16 \\
54.9 \pm 0.16\end{array}$ & $* *$ & $* *$ & NS \\
\hline $\begin{array}{l}\text { Shell \% at } 90 \text { days } \\
\text { of laying. }\end{array}$ & $\begin{array}{l}\mathrm{S} \\
\mathrm{C}\end{array}$ & $\begin{array}{l}10.8 \pm 10.1 \\
10.5 \pm 0.08\end{array}$ & $\begin{array}{l}11.2 \pm 0.07 \\
10.8 \pm 0.05\end{array}$ & $\begin{array}{l}11.7 \pm 0.14 \\
11.0 \pm 0.12\end{array}$ & $* *$ & $* *$ & $*$ \\
\hline Shell $\%$ at 45 wks. & $\begin{array}{l}\mathrm{S} \\
\mathrm{C}\end{array}$ & $\begin{array}{l}10.5 \pm 0.47 \\
10.2 \pm 0.09\end{array}$ & $\begin{array}{l}10.5 \pm 0.21 \\
10.3 \pm 0.03\end{array}$ & $\begin{array}{l}11.4 \pm 0.07 \\
10.6 \pm 0.13\end{array}$ & $* *$ & $* *$ & $*$ \\
\hline Shell $\%$ at 65 wks. & $\begin{array}{l}\mathrm{S} \\
\mathrm{C}\end{array}$ & $\begin{array}{l}9.9 \pm 0.11 \\
10.0 \pm 0.12 \\
\end{array}$ & $\begin{array}{l}10.1 \pm 0.11 \\
10.0 \pm 0.04\end{array}$ & $\begin{array}{l}10.7 \pm 0.17 \\
10.1 \pm 0.11\end{array}$ & $* *$ & $* *$ & NS \\
\hline Shell thickness, mm & $\begin{array}{l}\mathrm{S} \\
\mathrm{C}\end{array}$ & $\begin{array}{l}0.38 \pm 0.09 \\
0.37 \pm 0.06\end{array}$ & $\begin{array}{l}0.35 \pm 0.07 \\
0.35 \pm 0.08\end{array}$ & $\begin{array}{l}0.35 \pm 0.03 \\
0.34 \pm 0.09\end{array}$ & $* *$ & $* *$ & NS \\
\hline Shell thickness, mm & $\begin{array}{l}\mathrm{S} \\
\mathrm{C}\end{array}$ & $\begin{array}{l}0.35 \pm 0.06 \\
0.36 \pm 0.01\end{array}$ & $\begin{array}{l}0.34 \pm 0.01 \\
0.33 \pm 0.03\end{array}$ & $\begin{array}{l}0.34 \pm 0.01 \\
0.32 \pm 0.04\end{array}$ & $* *$ & $* *$ & NS \\
\hline Shell thickness, mm & $\begin{array}{l}\mathrm{S} \\
\mathrm{C}\end{array}$ & $\begin{array}{l}0.35 \pm 0.09 \\
0.35 \pm 0.04\end{array}$ & $\begin{array}{l}0.33 \pm 0.04 \\
0.32 \pm 0.07\end{array}$ & $\begin{array}{l}0.32 \pm 0.05 \\
0.31 \pm 0.02\end{array}$ & $* *$ & $* *$ & NS \\
\hline Hugh Unit & $\begin{array}{l}\mathrm{S} \\
\mathrm{C}\end{array}$ & $\begin{array}{l}84.7 \pm 1.22 \\
86.7 \pm 1.16 \\
\end{array}$ & $\begin{array}{l}80.5 \pm 1.26 \\
85.9 \pm 1.29\end{array}$ & $\begin{array}{l}82.4 \pm 1.25 \\
84.9 \pm 1.64\end{array}$ & $* *$ & $* *$ & $*$ \\
\hline Hugh Unit & $\begin{array}{l}\mathrm{S} \\
\mathrm{C}\end{array}$ & $\begin{array}{l}82.9 \pm 1.23 \\
84.9 \pm 1.78\end{array}$ & $\begin{array}{l}81.9 \pm 1.41 \\
84.4 \pm 0.82\end{array}$ & $\begin{array}{l}81.9 \pm 1.26 \\
83.7 \pm 1.43\end{array}$ & $*$ & $* *$ & $*$ \\
\hline Hugh Unit & $\begin{array}{l}\mathrm{S} \\
\mathrm{C}\end{array}$ & $\begin{array}{l}81.2 \pm 0.93 \\
83.9 \pm 1.27\end{array}$ & $\begin{array}{l}80.7 \pm 087 \\
80.7 \pm 1.25\end{array}$ & $\begin{array}{l}79.8 \pm 1.23 \\
80.5 \pm 089\end{array}$ & $*$ & $* *$ & NS \\
\hline
\end{tabular}

Line: $\mathrm{S}=$ Selected line \& $\mathrm{C}=\mathrm{Control}$ line

$\mathrm{NS}=$ Non significant, $*$ significant at $1 \%$ level of probability and $* *$ significant at $5 \%$ level of probability 
Table (4): Realized correlated response for unselected traits in the selected lines by generation in Dokki-4 strain.

\begin{tabular}{|c|c|c|c|}
\hline \multirow{2}{*}{ Traits } & \multicolumn{3}{|c|}{ Realized response } \\
\hline & G1 & G2 & Cumulative \\
\hline \multicolumn{4}{|l|}{ Egg production traits } \\
\hline Age at sexual maturity, day & -5.70 & -1.8 & -7.5 \\
\hline Duration period of the first 10 eggs, day & -1.35 & -1.13 & -2.48 \\
\hline Body weight at sexual maturity, $g$ & -5.8 & -0.2 & -6.0 \\
\hline Body weight at 90 days of laying, $\mathrm{g}$ & -44.0 & -10.3 & -54.3 \\
\hline Body weight at 65 wks, $g$ & -45.5 & 8.7 & -36.8 \\
\hline Egg number at 45 wks, egg & 14.30 & 6.80 & 21.10 \\
\hline Egg number at 65 wks, eggs & 16.50 & 9.40 & 25.90 \\
\hline Egg weight during the first 90 days, $g$ & -0.24 & -0.18 & -0.42 \\
\hline Egg weight at 45 wks, g & -0.05 & -0.15 & -0.20 \\
\hline Egg weight at 65 wks, $g$ & 0.08 & -0.21 & -0.13 \\
\hline Egg mass at first 90 days, $g$ & 343.7 & 379.9 & 723.6 \\
\hline Egg mass at $45 \mathrm{wks}, \mathrm{g}$ & 688.7 & 264.7 & 953.4 \\
\hline Egg mass at 65 wks, g & 799.9 & 426.8 & 1226.7 \\
\hline Feed conversion at 90 days of laying, & -0.65 & -0.52 & -1.17 \\
\hline Feed conversion 45 wks & -0.68 & -0.08 & -0.76 \\
\hline Feed conversion at 65 wks & -0.50 & -0.25 & -0.75 \\
\hline \multicolumn{4}{|l|}{ Average egg quality } \\
\hline shape index & 2.15 & -0.64 & 1.51 \\
\hline Yolk, \% & 0.92 & 0.63 & 1.55 \\
\hline Albumen, $\%$ & -0.71 & -0.94 & -1.60 \\
\hline Egg shell, \% & 0.17 & 0.31 & 0.48 \\
\hline Egg shell thickness, mm & 0.02 & 0.01 & 0.03 \\
\hline Haugh Unit, unit & 2.59 & -0.39 & 2.20 \\
\hline
\end{tabular}


Table (5): Heritability estimates $\left(h^{2} s\right)$, genetic $\left(r_{g}\right)$ and phenotypic $\left(r_{p}\right)$ correlations between egg number at the first 90 days of laying and correlated traits over two generations from sire components of variance.

\begin{tabular}{|l|l|l|l|}
\hline \multicolumn{2}{|c|}{ Traits } & \multicolumn{1}{c|}{$\mathbf{h}^{2}$} & \multicolumn{1}{c|}{$\mathbf{r}_{\mathbf{p}}$} \\
\hline Egg production & $0.21 \pm 0.33$ & & \\
\hline Egg number at the first 90 days of laying. & $0.38 \pm 0.03$ & $-0.320 \pm 0.31$ & -0.37 \\
Age at sexual maturity, day & $0.19 \pm 0.16$ & $-0.681 \pm 0.66$ & -0.47 \\
Duration period of first 10 eggs, day & $0.24 \pm 0.21$ & $-0.561 \pm 0.38$ & -0.19 \\
Body weight at sexual maturity, g & $0.46 \pm 0.14$ & $-0.11 \pm 0.01$ & -0.19 \\
Body weight at 90 days of laying, g & $0.41 \pm 0.21$ & $-0.19 \pm 0.38$ & -0.21 \\
Body weight at 65 wks, g & $0.19 \pm 0.03$ & $0.41 \pm 0.14$ & 0.46 \\
Egg number at 45 wks, egg & $0.23 \pm 0.09$ & $0.35 \pm .015$ & 0.27 \\
Egg number at 65 wks, eggs & $0.42 \pm .0 .17$ & $-0.13 \pm 0.08$ & -0.21 \\
Egg weight during the first 90 days, g & $0.29 \pm 0.21$ & $-0.531 \pm 0.29$ & -0.43 \\
Egg weight at 45 wks, g & $0.41 \pm 0.12$ & $-0.18 \pm 0.09$ & -0.34 \\
Egg weight at 65 wks, g & $0.43 \pm 0.21$ & $0.62 \pm 0.23$ & 0.81 \\
Egg mass at first 90 days, g & $0.38 \pm 0.42$ & $0.71 \pm 0.16$ & 0.86 \\
Egg mass at 45wks, g & $0.51 \pm 0.12$ & $0.56 \pm 0.15$ & 0.75 \\
Egg mass at 65 wks, g & $0.38 \pm 0.19$ & $-0.33 \pm 0.21$ & -0.33 \\
Feed conversion at 90 days of laying, & $0.24 \pm 0.01$ & $-0.34 \pm 0.09$ & -0.31 \\
Feed conversion 45 wks & $0.33 \pm 0.11$ & $-0.39 \pm 0.11$ & -0.41 \\
Feed conversion at 65 wks & $0.39 \pm 0.22$ & $-0.33 \pm 0.08$ & -0.16 \\
\hline Egg quality traits & $0.29 \pm 0.23$ & $0.27 \pm 0.01$ & 0.37 \\
\hline Shape index & $0.46 \pm 0.13$ & $0.46 \pm 0.16$ & 0.31 \\
Yolk, \% & $0.32 \pm 0.42$ & $0.42 \pm 0.18$ & 0.16 \\
Albumen, \% & $0.21 \pm 0.31$ & $-0.11 \pm 0.03$ & -0.28 \\
Egg Shell\% & $0.18 \pm 0.12$ & $0.17 \pm 0.07$ & 0.18 \\
Shell thickness & Haugh unit &
\end{tabular}




\section{REFERENCES}

Abd-Ella, M.M.M. (2006): Heritability and Genetic correlation of feed efficiency and some egg production traits in Baheij chicken strain. M. Sci. Thesis, Fac. of Agric. Alex. Univ., Saba-Bash, Egypt

Abd El-Ghany, F.A., (2005): Selection for improving some economic traits in developed Inshas chickens strain. Journal of productivity and development, volume 10, No. (2); 195-210.

Abd El-Ghany, F.A., (2006): Genetic studies for growth traits in Inshas strain. J. Agric. Sci. Mansoura Univ., 31 (2): 1301-1313.

Abd El-Halim, H.A. (1999): Selection and genetic analysis of some meat and egg production traits in local chickens. M.Sc. Thesis, Fac. of Agric., Alex. Univ., Egypt.

Abdou, A.M. (2006). Effect of selection for 8-week body weight of male broiler parents on the performance and genetic parameters of their progeny. Egypt. Poult. Sci 26(111) 1217-1240.

Abdou, F.H.; and Kolsted, N. (1979). Genetic analysis of a control population of white Leghorn hens. Agric. Univ. of Norway, Dep. Of Poult. and for Animal Science Report, No. 63.

Abdou, A.M.; and A.A., Enab (1994). A comparison between the efficiencies of restricted selection indices with different leveles of restriction in selection breeding programs for laying hens. The second Sci. Conf. on Poult. 12-12 Sep. Kafr El-Sheih, Egypt.

Akhtar, N; S. Mahmood; M. Hassan; and F. Yasmeen (2007). Comparative study of production potential and egg characteristics of Lyallpur Silver Black, Fayoumi, and Rhode Island Red Breeds of poultry. Pakistan Vet. J. 27(4): 184188.

Aly, O. M.; Nama A.Masaad; Nazla,Y. Abou El-Ella and Yousria, K. M. Afifi, $(2010$ b). Improving the productivity and reproductivity of Baheij chickens through crossing. Effect of up grading on B. egg production, egg quality and hatch traits. Egypt. Poult. Sci., 30 : 11511170.

Amin, E.M. (2008). Effect of crossing between native and commercial chicken strains on egg production traits. Egypt. Poult. Sci. 28: 327-349.

Balat, Magda, M.; Nadia A. El-Sayed; F.N. Soliman; and M.A. Kosba (1995). The effect of introducing dwarf gene to Mandarah strain on economically important traits. Egypt. Poult. Sci. 15: 43-71.

Balat, Magda, M.; Nazla Y. Abou ElElla; O. M. Aly and Hanan, H. Ghanem (2008). Selection for improving egg production in Mandarah chickens to maximize the net income. 1- Correlated responses heritability, genetic and phenotypic correlations among egg production and growth traits.. Egypt. Poult. Sci. 28 (II): 367-382.

Bain, M.M. (2005). Recent advances in the assessment of eggshell quality and their future application. World's Poult. Sci., 61: 268-277.

Brand, H. V. D., H.K. Parmeter and B. Kemp (2004). Effect of housing system cout door vs cages and age of laying hens on egg characteristics. Br. Poult. Sci.,45: 745-752.

Cavero, D.; M. Schmutz; W. Icken and R. Presinger (2011): Improving hatchability in white egg layer strains through breeding. Lohmann information 46(1):44. 
El-Itriby, A.A.and I.F., Sayed, 1966. "Dokki 4" A new breed of poultry. Agric. Res. Rev., Cairo; Vol., 44: 102-109.

El-Tahawy, W.S. (2000). Genetically improvement of some productive and reproductive traits in local chicken. M. Sc. Thesis. Fac. of Agric., Alex. Univ., Egypt.

El- Sayed, Nadia, A.; R.E., Rizk; M., Bahie El- Deen; and Hedaia, $M$. Shalan (2001). Effect of strain and dietary regimen on the performance of local chickens. Egypt. Poult. Sci. 21:1021-1038.

El-Wardany, A.M.; Soltan , M. E.;and Abdou, F.H. (1992). Correlated selection response to selection for some egg production traits in Norfa chickens. Menofiya J. Agric. Res. Vol., 17 (4) : 1833 -1863.

El-Wardany, A.M. and Abdou, F.H. (1993). Genetic analysis of tow strains of Norfa chickens under selection for egg number or size. 2Expected vs realized correlated response. Menofiya J. agric. Res., Vol., 18(1): 241-256.

Enab, A. A. (1982). Genetic analysis of some economic traits in chickens. M. Sc. These Fac. Of Agric. Minfiya Univ., Egypt.

Enab, A. A., A. M. El-Wardany and Abdou, F. H. (2001). Genetic and phenotypic parameters of some egg production traits and specific gravity of White Leghorn hens. $2^{\text {nd }}$ International conf. on Animal production\& Health in Semi-Arid Areas 4-6 Sept. 557-561.

Enayat, A.H., (2006). Selection for increasing egg production characters in two local strains of chickens. M.Sc.Thesis, Fac. Of Agric., Kafr El-Sheikh Tanta Univ. Egypt.

El-Full, E. A., A. A. Ali and N. E. Goher, (2001). Effect of standardization on path coefficient analysis of egg characteristics in different genetic groups of Fayoumi fowls. Egypt. Poult. Sci. 21 (111): 655-675.

Falconer, D.S.(1960). Selection of mice for growth on high and low planes of nutrition Gent. Rees. 1: 91-113.

Falconer, D.S. (1989). Introduction To Quantitative Genetic, John Wiley And Sons, New York, U.S.A.

Fairfull, R.W.; and R.S. Gowe (1990). Genetics of egg production in chickens. Chapter 29: 705-761. (Cited by Crawford, 1990).

Ghanem, Hanan H.A. (1995). Selection for age at sexual maturity in Alexandria chickens.M.Sc. thesis, Fac. Of Agric., Alex. Univ., Egypt.

Ghanem, H.H. (2003). Selection for low egg Yolk cholesterol level and correlated response for some economic traits in some native type strains.Ph.D. Thesis, Fac.of Agric. Alex. Uni., Egypt

Ghanem, Hanan, H. and Yousria (2013). Factors affecting hatching traits and post-hatch growth in two developed chicken strains. Egypt. Poult. Sci. 33 (111): 651-666

Guill, R.A.; and K.W. Washburn (1974). Genetic changes in efficiency of feed utilization of chickens maintaining body weight constant. Poult. Sci. 53:1146-1154.

Hamdy, S.M., M.A. Kosba and M.K. Shebl (1985). Parent-offspring reproductive and Fayoumi chickens. Alx. J. Agric. Res. 30: 1227-1245.

Haugh, R.R. (1937). The Haugh unit for measuring egg quality. US egg. Poult. Mag., 43: 522-555, 572-573.

Islam, M. A., S. M. Bulbul, G. Seeland and A. B. Islam (2001). Egg quality of different chicken genotypes in summer and winter. Pakistan J. of Biosocial Sci., 4:1411-1414.

Kosba, M.A.; M. Farghaly; M. Bahie ElDeen; and H.A. Abd- El-Halim (2002). Selection and genetic 
analysis of some egg production traits in local chickens. Egypt. Poult. Sci. 22: 681-696.

Kosba, M. A., Hassan, G. E., Hassan, M. F., Bahie El-Deen, M. and Hanna, Ghanem, H. (1997). Selection and correlated response for age sexual maturity in Alexandria chicken. 2nd Hungarian-Egyptian Conf., Godollo, 16-19 Sept. 1997.

Kosba, M.A.; M., Farghaly; M., Bahie El-Deen; and M.M., Iraqi; A.F.M., El-Laban; and H.A., Abd-ElHalim (2006). Genetic trends and evaluation for productive traits in Alexandria chickens. Egypt. Poult. Sci. 26 (IV): 1497-1513.

Lake, P. E. and M. Stewart (1978). Artificial insemination in poultry. Min. of Agric. Fish. Food, Bull. 213(London, HMSO).

Mertens, K. F. Bamelis, B. De. Ketelaere, M. Bain, E. Decuypere and J. De Bacerdemaeker

(2006).

Monitoring of egg shell breakage and egg shell strength in different production of chains of consumption eggs. Poul. Sci., 85:1670-1677.

Monira, Kn, M. Salahuddin, and G. Miah (2003). Effect of breed and holding period on egg quality characteristics of chicken. Poult. Sci., 2: 261-263.

Mostafa, M. Y. (1989). Genetical and physiological studies on ducks. M.Sc. Thesis, Fac. Of Agric., Kafr El-Sheikh, Tanta Univ., Egypt.

Nawar, A.N. (2009). Production of 3- way cross of chickens to improve egg production traits. M. Sc. Thesis, Fac. of Agric., Alex. Univ. (Damanhour Branch), Egypt.

Rayan,G.N.,M.y.Mahrous, A. Galal, and A.H.El-Attar (2013). Study of some productive performance and egg quality traits in two commercial layer strains. Egypt. Poult. Sci. Vol (33) $-11: 357-369$.
Robert, J. R. (2004). Factors affecting egg internal quality and egg shell quality in laying hens. J. Poult. Sci. 41: 161-177.

Rizk, R.E.; Nadia A. El-Sayed; E.H.A. Shahein and Hedaia, M. Shalan (2008). Relationship between egg shell, egg shell membranes and embryonic development through different egg production periods in two developed chicken strains. Egypt. Poult. Sci., 28: 535-551.

Saleh, K.; T.M. El-Sayed and N. Hataba (1994). Results of random sample test of twelve native strains of shickens. The 2nd Sci. Conf. on Poult. 12-13 Sept., Kafr-El-Sheikh, Egypt

Saleh, K.; H.H. Younis; F. Abd ElGhany; and Enayat A. Hassan (2006). Selection and correlated response for egg production traits in Inshas and Silver Montazah strain of chickens. Egypt. Poult. Sci. 26: 749-770.

SAS Institute (1988). User, s Guide Statistics. SAS Institute INC., Cary, NC, USA.

Shalan, H.M., Nadia, A. El-Sayed and R. E., Rizk (2012). Estimates of genetic parameters for egg production and egg quality in local chicken strains.Egypt. Poult. Sci. 32 (11): 399-411

Sharma, D.; D.C. Johari; M.C. Kataria; R.C. Hazary; D. Choudhari; and S.C. Mohapatra (1998). Factors affecting direct and correlated responses in a White Leghorn population under long-term selection for egg number. Br. Poult. Sci. 39(1): 31-38.

Shebl, M. K., M. Soltan, M. A. Kosba and F. H. Abdou (1991). Environment interactions for growth and reproduvctive traits in Norfa chickens. Menofiya J. Agric. Res. Vol., 16 (2) : 1439 -1455. 
Singh, R.P; R.J., Kumar; and D.S., Balaine (1986). Genetic and phenotypic of production traits in a population of White Leghorn under selection. Ind. J. Poult. Sci. 21:1-4.

Singh, R., K. M. Cheng, and F. G. Silversides (2009). Production performance and egg quality of four strains of laying hens kept in conventional cages and floor pens. Poult. Sci. 88: 256-264.

Soltan, M.E. (1991). Direct response in egg production from selection on early part records and correlated response in some economic traits a result of this selection in Sinai (Bedouin) fowl. Minufiya J-Agric. Res. Vol . 16 (1) : 373-417.

Suk, Y.O.,C.Park (2001). Effect of breed and age of hens on the yolk to albumen ratio in two different genetic stocks Poult. Sci. 80: 855858.

Tawfeek , M. J. (1988). Improvement of methods of early appreciation and selection of poultry according to a complex of indication. Ph. D. Thesis, Academic of Agriculture, Keive, USSR.

Toussant, M. J.; and J. D. Latshaw (1999). Ovomucin contents and composition in chicken eggs with different interior quality. J. Sci. Food and Agri., 79:1666-1670.

Yasmeen F., S. Mahmood, M. Hassan, N. Akhtar and M. Yaseen (2008). Comparative productive performance and egg characteristics of pullets and spent layers Pakistan Vet. J., 28(1):5-8.

Younis, H.H.; and F.A. Abd EL-Ghany (2004). Direct and correlated response to selection for egg number in Silver Montazah chickens. Egypt. Poult. Sci. 24: 701718.

Zhang, LC.;ZH. Ning; GY. XU; Z. Chou and N.Yong (2005). Heritability and genetic and phenotypic correlation of egg quality traits in brown egg dwarf layers. Poult. Sci. 84: 1209-1213. 


\section{الملخص العربي}

التحسين الوراثى على صفات إنتاج البيض فى سلالة الدقى- ع

ا ـ الأستجابة المرتبطة، المكافئ الوراثى، الإرتباط الوراثى والمظهرى لإنتاج البيض وجودة البيض

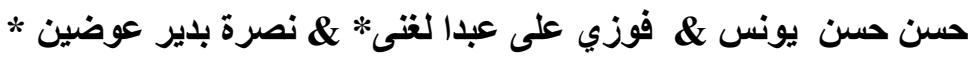

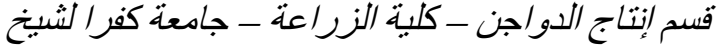

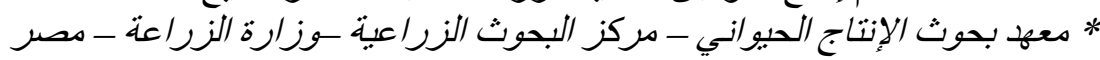

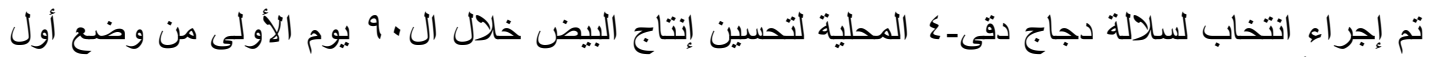

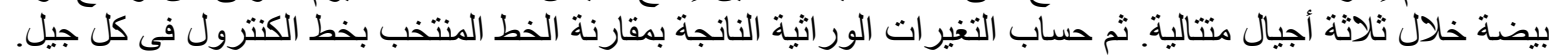

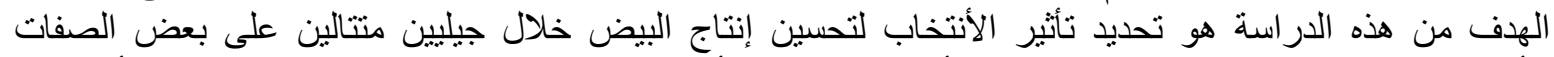

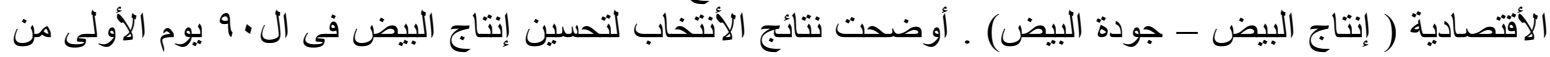

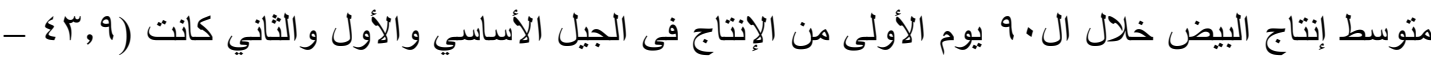
الإنتاج :

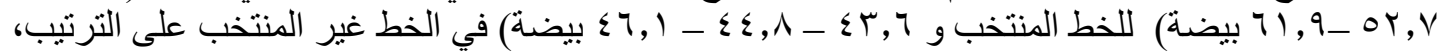

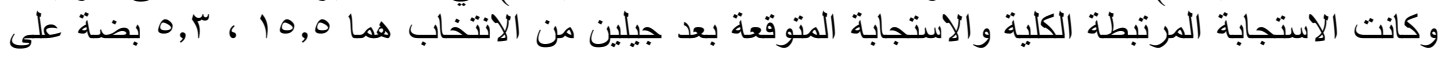
الترتيب .

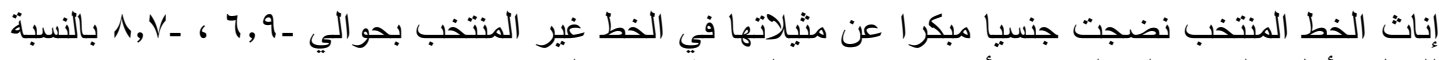

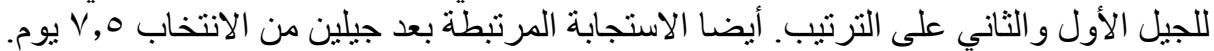

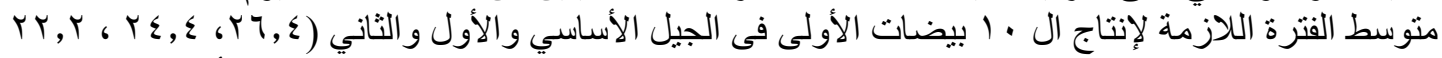

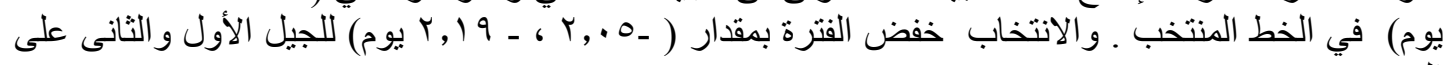
الترنيب.

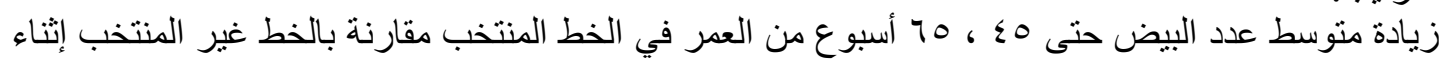

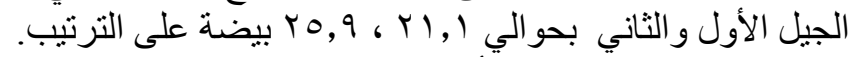

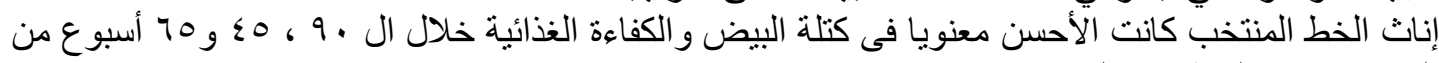

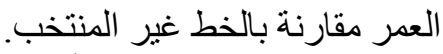

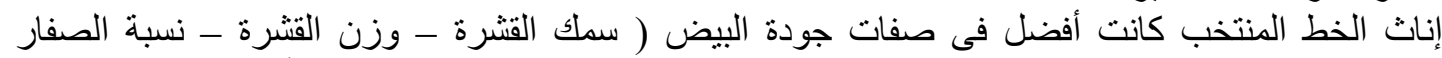
ووحدات هوف) عندما قورنت بإناث الخط غير المنتخب. معظم الصفات المدروسة ذات التات أنثير ات عالية المعنوية

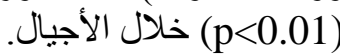

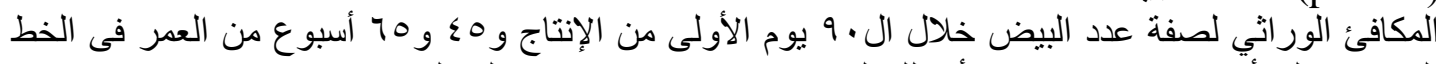

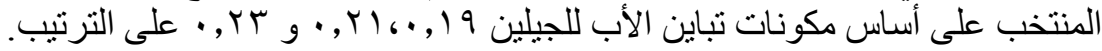

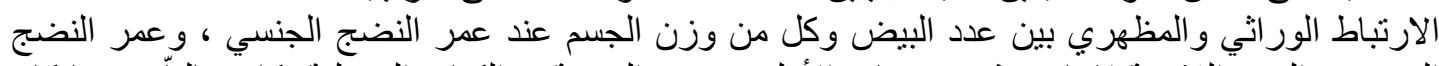

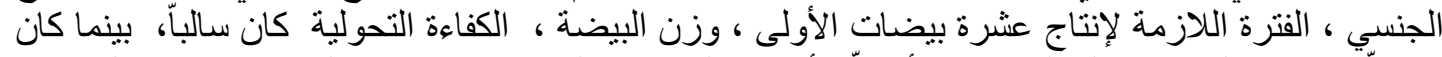

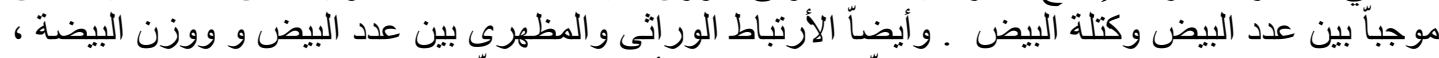

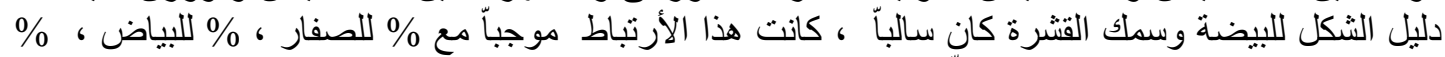

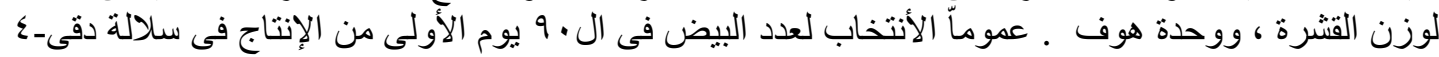

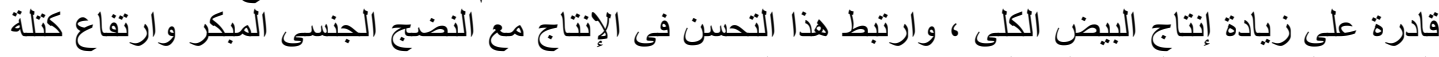
البيض و التحسن فى الكفاءة النحولية وصفات جودة البيض البيض 